\title{
POPKULTUROWY ZWROT W ROZWOJU DOGMATÓW?
}

\section{WSTĘP}

Kultura popularna, która (nie tylko) w świecie Zachodu rozkwita pod wpływem nieustających rewolucyjnych zmian w dziedzinie technologii, szczególnie medialno-komunikacyjnych, jest dzisiaj dominującą postacią kultury. „Niewątpliwie popkultura stanowi bardzo istotny element współczesnej rzeczywistości, jest dla członków społeczeństw państw zachodnich podstawowym źródłem obowiązującej wiedzy, wzorów myślenia i schematów postępowania. Można ją odmiennie wartościować, nie sposób jednak ignorować olbrzymiej roli, jaką odgrywa w konstruowaniu ponowoczesnej rzeczywistości. W ujęciu funkcjonalnym kultura popularna pełni ważną funkcję w transmisji kulturowego dziedzictwa, kształtuje systemy wartości, nadaje statusy społeczne, kreuje rytuały, a nawet stanowi siłę napędową do wprowadzania zmian społecznych czy tworzenia innowacji"'.

Dzisiaj podstawowe doświadczenia ludzi dokonują się w granicach kultury popularnej. Jest ona także krainą wyznawców Chrystusa,

1 A. Cybal-Michalska, P. Wierzba, Wprowadzenie, w: A. Cybal-Michalska, P. Wierzba (red.), Dyskursy kultury popularnej w społeczeństwie współczesnym, Kraków 2012, s. 9. 
którzy, podobnie jak inni obywatele tego świata, chcąc nie chcąc, w tym czy innym stopniu, bardziej lub mniej bezpośrednio, żyją w jej ramach, korzystają z jej narzędzi, należą do niej i ją współtworzą. Pomyślmy choćby o naszych, polskich, kremówkach Jana Pawła II, kolejnym kulinarnym hicie siostry Anastazji jezuickiego Wydawnictwa Apostolstwa Modlitwy, Languście na palmie o. Adama Szustaka, rzeszy tzw. katocelebrytów, na czele ze śp. ks. Janem Kaczkowskim, dewocjonaliach sprzedawanych na Jasnej Górze, Ewangelii według świętego zioma Janka, fankach i fanach bestsellerowej książki i filmu Chata, miłośnikach kryminałów Agaty Christie, czarnej koszulce z różowym napisem „Dziewczyny [z agencji towarzyskiej] czekają 24h na twoją modlitwę” kwartalnika „Fronda” czy o katolikach, którzy zakupy robią w ,świątyniach” wielkich centrów handlowych, oglądają serial Mjak miłość, dzielą się swoim życiem na Facebooku, marzą o selfie z papieżem Franciszkiem, czytają „Fakt”, podniecają się fake newsami, a prawdy szukają w Wikipedii itd. Nie da się uciec od popkultury, stanąć obok, spojrzeć na nią z wysoka lub wyniośle odwrócić od niej wzrok. W krainie popkultury spotykamy się z Bogiem, który umiłował świat, konkretny, popkulturowy - i pragnie wszystkich przyciągnąć do siebie.

W świecie kultury popularnej na naszych oczach - i w nas, ludziach religijnych - dokonują się zmiany w przeżywaniu i wyrażaniu religijności, więzi z Bogiem i relacji ze społecznością wiary, i to bez względu na to, czy mamy tego świadomość czy nie, czy się na to godzimy czy nie. Kierunek, a ściślej mówiąc, kierunki tych i wszystkich innych kulturowych zmian, bo mamy tu do czynienia z dynamiczną wielopostaciową płynną różnorodnością, wciąż wymykają się diagnozie. „Znajdujemy się w toku rewolucji komunikacyjnej o intensywności głębinowej i zasięgu planetarnym. Jej możliwe rezultaty nie są jeszcze znane, a nawet nie mogą być zasadnie przewidywane. Ale nie pozostawi ona żadnego wymiaru kultury ludzkiej ani żadnego zakątka na tej ziemi nietkniętymi”"2.

2 A. Mencwel, Przyczyniać się pomału, w: G. Godlewski i in. (red.), Animacja Kultury. Doświadczenie i przyszłość, Warszawa 2002, s. 20. 
Dokonujące się komunikacyjno-kulturowe zmiany w religijności i religii w ten czy inny sposób dotyczą, muszą dotyczyć także tego aspektu wiary Kościoła, do którego teologia odnosi pojęcia aktualizującej interpretacji oraz rozwoju dogmatów, który - mówiąc ogólnie - polega na zachodzeniu w dziejach Kościoła zmian w rozumieniu wiary, wyrażonej w orzeczeniach dogmatycznych, przy zachowaniu jej tożsamości³. I sprawie relacji zachodzącej między tym rozwojem a kulturą popularną, głównie zaś uzasadnieniu potrzeby „popkulturowego zwrotu" w ramach evolutionis dogmatum, poświęcam te rozważania. Sugeruję, że język (języki) kultury popularnej dojrzał do tego, by nazywać i przekazywać wielkie tajemnice wiary, którym Kościół nadał postać dogmatów (w sensie szerszym i ścisłym) ${ }^{4}$.

Niniejszy artykuł traktuję zaledwie jako przyczynek, może punkt wyjścia do dyskusji czy rozmowy, mając świadomość, że w naszych czasach do rozmowy tej teologia musi zaprosić inne nauki, szczególnie nauki społeczne.

\section{TRANSFORMACJA KULTUROWA}

Na półkach bibliotek teologicznych ze świecą szukać literatury poświęconej zagadnieniu relacji między rozwojem dogmatów i kulturą popularną. Może jest to $\mathrm{w}$ jakiejś mierze konsekwencja tego, że pojęcia ,popkultura”/,kultura popularna” z jakichś racji (podejrzliwość? dystans? niepewność? czekanie na rozwój wypadków?) jak na lekarstwo w dokumentach kościelnych. Nie znajdziemy go np. w takich ważnych dla refleksji na temat evolutionis dogmatum enuncjacjach Międzynarodowej Komisji Teologicznej (dalej MKT)

${ }^{3}$ Na temat rozwoju dogmatów zob.: Z. Kijas, Rozwój dogmatów i jego kryteria, w: T. Dzidek, i in. (red.) Teologia fundamentalna t. 5 Poznanie teologiczne, Kraków 1997, s. 72-87; J. E. Thiel, The Development of Doctrine, w: J. Buckley i in. (ed.), The Blackwell Companion to Catholicism, Oxford 2011, s. 251-267;T. G. Guarino, Vincent of Lérins and the Development of Christian Doctrine, Grand Rapids 2013.

${ }^{4}$ Międzynarodowa Komisja Teologiczna, Interpretacja dogmatów (1988), (tłum.) J. Królikowski, w: Od wiary do teologii. Dokumenty Międzynarodowej Komisji Teologicznej, 1969-1996, red. J. Królikowski, Kraków 2000, s. 286-288. 
jak Interpretacja dogmatów czy Wiara i inkulturacja (1988), gdzie jakby się zdawało - nie powinno już go zabraknąć. Nie ma go nawet w trzech ostatnich dokumentach tego gremium, które powstały już w drugiej dekadzie XXI w., w czasach dynamicznego rozkwitu popkultury oraz wielkiego przyspieszenia w jej badaniach socjologiczno-antropologicznych: Teologia dzisiaj (2012), Trójca Święta, jedność ludzi (2014) i ,,Sensus fidei” w życiu Kościoła (2014).

Z kolei na internetowej watykańskiej stronie Papieskiej Rady Kultury (dalej PRK) znajduje się 13 dokumentów tej dykasterii - cultura popolare występuje tylko w jednym z nich: Dov'è il tuo Dio? La fede cristiana di fronte alla sfida dell'indifferenza religiosa. Documento finale dell'assemblea plenaria (2004) - tyle że w znaczeniu „kultury ludowej”, a nie „kultury popularnej”5.

Podobny - „ludowy”, a nie ,popkulturowy” - sens ma cultura popolare w adhortacji Franciszka Evangelii gaudium: „Autentyczne formy religijności ludowej są wcielone, ponieważ wyłoniły się z wcielenia wiary chrześcijańskiej w kulturę ludową (cultura popolare)" (nr 90; por. 68 i 69) 6 . Papież nie posłużył się pojęciem ,popkultury” w żadnej ze swoich dotychczasowych encyklik i adhortacji ani w żadnym orędziu na Światowy Dzień Środków Społecznego Przekazu. Z kolei pojęcie „kultura popularna” w adhortacjach, encyklikach i orędziach na ten sam światowy dzień pióra Benedykta XVI występuje tylko w jednym dokumencie, gdzie ma charakter czysto „popkulturowy” - w pierwszym takim orędziu tego papieża: „Nie można bagatelizować wielkiego wpływu, jaki wywierają [...] media elektroniczne. Właśnie dlatego, że współczesne media kształtują

5 PRK, Dov'è il tuo Dio? La fede cristiana di fronte alla sfida dell'indifferenza religiosa. Documento finale dell'assemblea plenaria, http://www.vatican.va/roman_curia/pontifical_councils/cultr/documents/rc_pc_cultr_doc_20040313_where-is-your-god_it.html (dostęp: 2.03.2018)

6 Franciszek, Adhortacja apostolska „Evangelii gaudium” o głoszeniu Ewangelii w dziesiejszym świecie, nr 68-69, 90, http://w2.vatican.va/content/francesco/pl/ apost_exhortations/documents/papa-francesco_esortazione-ap_20131124_evangelii-gaudium.html (dostęp: 2.03.2018). 
masową kulturę (cultura popolare), one same muszą przezwyciężyć wszelką pokusę manipulacji [...]"7.

Nieobecność „kultury popularnej” w przywołanych dokumentach nie znaczy oczywiście, że nie znajdziemy w nich diagnozy współczesnej kultury. Np. Benedykt XVI w orędziu Nowe technologie, nowe relacje (2009) zaprezentował jej ważną syntezę: „,...] pod wpływem nowych technologii cyfrowych ulegają zmianie podstawowe modele komunikacji i relacje międzyludzkie. Zmiany te są szczególnie widoczne wśród ludzi młodych, którzy wychowali się w ścisłym kontakcie z nowymi technikami komunikacji i dobrze się czują w cyfrowym świecie [...]"8. Z kolei w roku $2011 \mathrm{w}$ orędziu Prawda, przepowiadanie i autentyczność życia werze cyfrowej kontynuował: ,[...] tak jak rewolucja przemysłowa spowodowała głębokie przemiany społeczne poprzez nowości wprowadzone do cyklu produkcyjnego i w życie pracujących, tak zachodząca dziś głęboka przemiana w dziedzinie komunikacji kieruje nurtem wielkich przemian kulturowych i społecznych. Nowe technologie zmieniają nie tylko sposób komunikowania się, ale także komunikację samą w sobie, i można z tego powodu stwierdzić, że stajemy w obliczu szerokiej transformacji kulturowej. Wraz z takim sposobem rozpowszechniania informacji i wiedzy rodzi się nowy sposób uczenia się i myślenia, z bezprecedensową możliwością nawiązania kontaktów i budowania wspólnoty"9. Tu widzę jedną z podstawowych racji za „popkulturowym zwrotem” w rozwoju dogmatów.

7 Benedykt XVI, Orędzie na XL Światowy Dzień Środków Społecznego Przekazu „Środki przekazu: sieć komunikacji, jedności i wspótpracy”, https://www.paulus. org.pl/227,40-sdssp-benedykt-xvi-2006 (dostęp: 2.03.2018).

8 Benedykt XVI, Orędzie na XLIII Światowy Dzień Środków Społecznego Przekazu „Nowe technologie, nowe relacje. Trzeba rozpowszechniać kulturę szacunku, dialogu i przyjaźni”, http://www.opoka.org.pl/biblioteka/W/WP/benedykt_xvi/ przemowienia/massmedia2009_24012009.html (dostęp: 15.01.2014).

9 Benedykt XVI, Orędzie ná XLV Światowy Dzień Środków Społecznej Komunikacji „Prawda, przepowiadanie i autentyczność życia w erze cyfrowej”, https:// www.paulus.org.pl/222,45-sdssp-benedykt-xvi-2011 (dostęp: 2.03.2018). 
Dogmaty powstały w technologicznie i komunikacyjnie radykalnie innej, „starej” kulturze, niż ta, która rozkwita i w której żyjemy dzisiaj. By je zrozumieć w wierze, potrzebują „starego” sposobu myślenia, uczenia się, pojmowania relacji międzyludzkich i wspólnoty. Tymczasem obecnie gwałtownie rodzi się nieznany wcześniej, „nowy” sposób myślenia, uczenia się, pojmowania relacji międzyludzkich i wspólnoty, które raczej nie przystają do „starego” języka dogmatów. Wydaje się zatem, że bez ich przełożenia na „nowy” język, język popkultury, ich życiodajne, zbawcze treści mogą nie trafić ze zrozumieniem do adresatów.

\section{POLIMORFICZNA HYBRYDA}

W niektórych środowiskach kultura popularna nieodmiennie jest krytykowana. W 2004 r. Bartłomiej Dobroczyński pisał w tekście Trzecia Rzesza Popkultury: „Stwierdzamy [...] upadek wartości. Skarżymy się na wszechobecność chamstwa, mówimy o zalewie przemocy i dehumanizującego seksualizmu w mediach oraz o tym, że kulturę zdominowały tematy trywialne, drugorzędne i «pozorne». Lamentujemy, iż w telewizji programy rozrywkowe i filmy są głupie i urągają wrażliwości oraz inteligencji widzów"10.

W krainie popkultury, owszem, łatwo można znaleźć zjawiska negatywne, także antychrześcijańskie, niemniej jednak pod pewnymi względami dzisiaj przypomina ona kulturę ludową: sporo w niej negatywów, ale jednocześnie równie wiele pozytywów. O paradoksalnej naturze kultury ludowej przypomniał Franciszek: ,Zewangelizowana

10 B. Dobroczyński, Trzecia Rzesza Popkultury, „Znak” 2004, nr 3, s. 16-17, 19. Co do krytyki kultury popularnej w perspektywie negatywnego jej wpływu na religię zob. np.: K. Koehler, Uwiedzeni własną perswazją. Współczesna kultura chrześcijańska a popkultura, w: T. Chachulski, J. Snopek, M. Ślusarska (red.), Religijność $w$ dobie popkultury, Warszawa 2014, s. 25-35; Z. Mikołejko, Religia bez właściwości, ibidem, s. 11-17; I. Bajerowa, Szanse języka religijnego wświecie kultury masowej, w: Z. Adamek (red.), Teologia-kultura-współczesność, Tarnów 1995, s. 99-113; E. Wolicka, Obraz i słowo w obszarze języka religijnego, „Znak” 1995, nr 12, s. 64-75. 
kultura ludowa (cultura popolare) zawiera wartości wiary i solidarności, które mogą spowodować rozwój społeczeństwa bardziej sprawiedliwego i wierzącego, oraz posiada szczególną mądrość. [...] Każda kultura i każda grupa społeczna potrzebuje oczyszczenia i dojrzewania. W przypadku katolickich kultur ludowych (culture popolari) możemy uznać niektóre słabości, które powinny być jeszcze uzdrowione przez Ewangelię: nadmierna dominacja mężczyzny (machismo) $)^{*}$, alkoholizm, przemoc domowa, znikome uczestnictwo w Eucharystii, wierzenia fatalistyczne lub zabobonne, skłaniające, by uciekać się do czarów itp. Ale właśnie pobożność ludowa jest najlepszym punktem wyjścia do ich uzdrowienia i wyzwolenia" (nr 68-69).

Marian Golka przedstawił listę najczęściej wymienianych pozytywnych stron popkultury:

- popularność, która może być też kryterium pozytywnym;

- demokratyzacja odbioru tzw. kultury wyższej;

- działania edukacyjne i dydaktyczne;

- wypełnienie luki po kulturze ludowej;

- wspieranie integracji społecznej;

- odpowiedź na alienację dnia codziennego;

- zaspokajanie ambiwalentnych gustów odbiorców;

- kultura masowa nie musi zakłócać realizacji innych przejawów twórczościll.

Kultura popularna jest płynnym, hybrydycznym, polimorficznym „bytem”, wewnętrznie popękanym, podzielonym i sprzecznym, która „wytworzyła już we własnym obrębie precyzyjne hierarchie wartościowania produktów, ma już własne sub- i kontrkulturowe działania. Nie jest więc wyłącznie [...] wszechogarniającą i ogłupiającą papką. Podobnie zróżnicowani są [jej] odbiorcy [...] Potęga kultury popularnej wynika właśnie z faktu, że tak wielka jest jej

* Fraza „nadmierna dominacja mężczyzn” to wymysł tłumacza adhortacji, we włoskim oryginale mamy tu jedno słowo: il maschilismo, czyli „machismo”, oznaczające samczość, kult silnego, władczego, wyjątkowo sprawnego seksualnie „prawdziwego mężczyzny”.

11 M. Golka, Socjologia kultury, Warszawa 2013, s. 165-168. 
oferta i zróżnicowanie"12. Jako taka - to kolejna racja za „popkulturowym zwrotem" rozwoju dogmatów - wychodzi naprzeciw egzystencjalnym i duchowym potrzebom ludzi, pomaga im radzić sobie z tragicznością i trudnościami ludzkiego życia, ze śmiercią, chorobą, cierpieniem, troską o najbliższych, samotnością, konfliktami, stresem, depresją... - w nadziei na lepsze życie ${ }^{13}$. Czyż nie jest to również cel dogmatów?

\section{ZACZAROWANIE ŚWIATA}

Taką popkulturową krainę tworzymy my, ludzie różnych stanów, języków, wykształcenia, uposażenia, światopoglądów, religii. Wbrew scenariuszom proroków sekularyzacji XX w., racjonalizm i modernizacja nie doprowadziły do zaniku religii/religijności na Zachodzie, tym bardziej poza jego granicami ${ }^{14}$. Mimo odczuwalnych skutków „odczarowywania świata” (Entzauberung der Welt Maxa Webera), popkultura, na czele z mediami, raczej ujawnia tendencje desekularyzacyjne. Gęsta jest od treści o charakterze religijnym, rytualnym, duchowościowym, mitologicznym czy paranormalnym. Zachód podlega nie „odczarowaniu”, ale „zaczarowaniu”15.

W kulturze popularnej religijność nie zanika, ale podlega przeobrażeniom. Ważne przy tym jest, że popkultury dzisiaj - w przeciwieństwie do kultury masowej - nie da się już lokować wyłącznie po stronie jej wytwórców i nadawców, producentów popkulturowych

12 W.J. Burszta, Kultura popularna jako wspólnota uczuciowa, „Kultura Popularna" 2002, nr 0, s. 15 i 17.

13 Por. W.J. Burszta, Zastuchani w te same opowieści. Z Wojciechem J. Burszta rozmawiaja D. Pycińska i M. Żyła, „Znak” 2010, nr 3, s. 19. Zob.: J. Majewski, Religia, media, mitologia, Gdańsk 2010, s. 73-95.

${ }_{14}$ Zob. P. Berger, J. Sacks (ed.), The Desecularization of the World: Resurgent Religion and World Politics, Grand Rapids 1999; J. Mariański, Sekularyzacja, desekularyzacja, nowa duchowość. Studium socjologiczne, W. Pawluczuk, Kraków 2013.

15 J. Barański, Antropologia, między przed-a ponowoczesnościa-garść wróżby na nowy wiek, „Konteksty” 2005, nr 4, s. 148. 
produktów i idei, jakby tylko oni byli aktywnymi podmiotami kultury, jednostronnie narzucającymi swoje idee biernym odbiorcom, mającym tworzyć jednorodną społeczność bezwolnych konsumentów. Kultura popularna dynamicznie i dialektycznie rozwija się też po stronie odbiorców, którzy - szczególnie dzięki Internetowi - sami stają się jej autorami i współtwórcami. Tworzą społeczność zróżnicowanych aktywnych podmiotów, interpretujących rzeczywistość w perspektywie zróżnicowanych hierarchii wartości i w różnorodnych kontekstach egzystencjalno-społecznych. W tym świetle popkulturę można pojmować ,jako wspólne środowisko, praktyki i zasoby codziennego życia"16, obejmujące aktywność po stronie nadawców, którzy sami są odbiorcami popkultury, jak też codzienne praktyki ich adresatów, np. ,gotowanie, jedzenie, opieka nad dziećmi i innymi ludźmi, spędzanie czasu w pracy, jak i z przyjaciółmi, życie seksualne, sprzątanie, naprawy domowe, pranie, ubranie czy bujanie w obłokach"17, korzystanie z Internetu, chodzenie do kina, lektura gazet, robienie zakupów, uprawianie sportu itd.

W takiej dynamicznej krainie popkultury religijność podlega przeobrażeniom. Nie bardzo wiadomo, dokąd procesy te prowadzą, ale chyba można już mówić o kształtowaniu się religijności z przydawką popularna $^{18}$. Badacze, starając się uchwycić (płynne) linie tej ewolucji na obecnym etapie, zwykle zdają się zgadzać ${ }^{19}$ przynajmniej co do tego, że:

16 G. Lynch, Understanding Theology and Popular Culture, Oxford 2005, s. 14.

17 Tamże, s. 15.

18 Zob. M. Zowczak, Między tradycją a komercja, ,Znak”, 2008, nr 3, http://www. miesiecznik.znak.com.pl/6342008magdalena-zowczakmiedzy-tradycja-a-komercja/ (dostęp: 2.03.2018); zob. J. Drozdowicz, Popreligia $w$ dobie popkultury, w: E. Jeliński i in. (red.), Ratio, religio, humanitas, Poznań 2015, s. 229-236; P. Cybulska, J. Majewski, Narodziny popreligii, „Sensus Historiae” 2017, vol. XXVII, s. 95-110.

19 Korzystam m.in. z: W. Kawecki, Kultura konsumpcyjna a wychowanie do kultury wysokiej, „Studia Theologica Varsaviensia” 2010, nr 2, s. 177-197; B. Dziadzia, Naznaczeni popkulturą, Gdańsk 2014, s. 167-215; M. Zowczak, Religijność na pograniczach. Eseje apokryficzne, Warszawa 2014; G. Davie, The Sociology of Religion: A Critical Agenda, London 2013; G. Lynch (ed.), Between Sacred and Profane: Researching Religion and Popular Culture, London 2007; 
- religijność decentralizuje się i demokratyzuje, w efekcie mamy do czynienia z kryzysem tradycyjnego autorytetu religijnego wierzący są coraz mniej wierni dyrektywom instytucji i ich zwierzchników, doktrynom i dogmatom;

- religijność komercjalizuje się i podlega prawom konsumpcji i rynku;

- religijność przyjmuje postać eklektyczną i hybrydyczną, czemu sprzyja Internet, z możliwością dowolnego czerpania idei z różnych religii i duchowości pozostających w ,supermarkecie" o rozmiarach globalnych, w efekcie faktem staje się nieznany wcześniej pluralizm religijno-duchowościowy;

- w religijności traci na znaczeniu to, co racjonalne i logiczne, a rośnie znaczenie irracjonalności, uczuciowości i empatyczności;

- w religijności coraz większą rolę odgrywa szczególny rodzaju indywidualizmu, czemu zdaje się towarzyszyć nowe pojmowanie wspólnotowości;

- wiele praktyk i cech, zwykle wiązanych z religijnością ludową, doznaje umocnienia, ,a pielgrzymki, misteria i kult obrazów cieszą się nieustającą popularnością", podobnie sensualizm, „który [jednak] subiektywizuje się” i tworzy „nową konfigurację z ekspresywizmem i ludycznością, a także, czy może przede wszystkim, fascynacją medialnymi obrazami i spektaklem"20.

\footnotetext{
A. Possamai, Sociology of Religion for Generations $X$ and $Y$, London - New York 2014; H.A. Campbell (ed.), Digital Religion. Understanding Religious Practice in New Media Worlds, London - New York 2012; L. Christoffersen i in. (ed.), Religion in the 21st Century: Challenges and Transformations, Farnham-Burlington 2013; B. S. Turner (ed.), New Blackwell Companion to the Sociology of Religion, Oxford 2010; J. Majewski, The Church in the Media Age, w: T. Buksiński (ed.). Dilemmas of the Catholic Church in Poland, Washington 2015, s. 41-66.

${ }^{20}$ M. Zowczak, Między tradycja a komercja, art. cyt.
} 


\section{OBCA ORTODOKSJA}

W refleksji Benedykta XVI o kulturze współczesnej wybija się pytanie o język i komunikację. W 2010 r. papież powiedział: „Komunikacja i język są także istotnymi wymiarami kultury ludzkiej, na którą składają się informacje i pojęcia, wierzenia i style życia, a także reguły, bez których ludziom trudno byłoby doskonalić się w człowieczeństwie i relacjach społecznych. [...] dokonuje się głęboka przemiana kulturalna, niosąca z sobą nowe języki i nowe formy komunikacji, które sprzyjają także powstawaniu nowych, problematycznych rodzajów antropologii"21.

Stanowisko Benedykta XVI pod jakimś względem zdaje się bliskie pojmowaniu komunikacji i kultury szkoły z Toronto (Eric Havelock, Marshal McLuhan, Walter J. Ong czy Derrick de Kerckhove) ${ }^{22}$, według której dominujące w konkretnych okresach historii środki komunikacji - jak słowo, pismo, druk, media audiowizualne, multimedia - „nie tylko są odrębnymi formami komunikacji, powołującymi do życia swoiste zachowania i praktyki komunikacyjne, ale również wytwarzają właściwe sobie role i instytucje kulturowe, więcej, modelują same podstawy kultury: poczynając od kulturowo warunkowanych zasad percepcji, poznania i myślenia, poprzez wzory relacji i więzi międzyludzkich, po zasady organizacji życia zbiorowego. Promieniując na wszystkie tego rodzaju sfery, środki przekazu [...] zdolne są $\mathrm{w}$ istocie do generowania całościowych typów kultury"23. Współczesna „zmiana dominanty komunikacyjnej” (Andrzej Mencwel) dotyczy również religii i religijności, które do-

${ }^{21}$ Benedykt XVI, Przemówienie do uczestników zgromadzenia plenarnego Papieskiej Rady Kultury ,Nowe i kreatywne języki, pozwalajace prowadzić dialog ze wszystkimi" (13.11.2010), https://opoka.org.pl/biblioteka/W/WP/benedykt_xvi/ przemowienia/radakultury_13112010.html (dostęp: 2.03.2018).

22 Zob. G. Godlewski, Stowo - pismo - sztuka stowa. Perspektywy antropologiczne, Warszawa 2008.

${ }^{23}$ G. Godlewski, Jack Goody, uczony w piśmie. Wstęp do wydania polskiego, [w:] J. Goody, Logika pisma a organizacja społeczeństwa, przekład, wstęp i redakcja G. Godlewski, Warszawa 2006, s. 12. 
świadczają głębokich przeobrażeń. Trudno się dziwić że - jeszcze raz Benedykt XVI - „W tej sytuacji duszpasterze i wierni doświadczają pewnych budzących troskę trudności w głoszeniu przesłania ewangelicznego i w przekazywaniu wiary [...]"24.

Ponad 20 lat wcześniej podobną myśl wyraziła MKT, pisząc w odniesieniu do rozwoju dogmatów - że we współczesnej ,,[...] kulturze tradycyjny język dogmatyczny Kościoła nie wydaje się być już bezpośrednio zrozumiały, o ile nie prowadzi nawet do złego rozumienia, także dla wielu chrześcijan. Co więcej, niektórzy uważają go za przeszkodę w żywym przekazywaniu wiary"25. Jeszcze dalej idzie refleksja Franciszka: „Niekiedy wierni słuchając języka ściśle ortodoksyjnego, wynoszą coś całkowicie obcego autentycznej Ewangelii Jezusa Chrystusa, ze względu na język przez nich używany i rozumiany. Mając święty zamiar przekazania im prawdy o Bogu i człowieku, przekazujemy im w pewnych sytuacjach fałszywego boga lub ideał ludzki, który naprawdę nie jest chrześcijański. W ten sposób pozostajemy wierni jakiemuś sformułowaniu, ale nie przekazujemy istoty rzeczy" (nr 41).

Franciszek nie wskazał żadnej konkretnej doktryny głoszonej „językiem ściśle ortodoksyjnym”, ale wiodącym na manowce - i nie tu miejsce na podawanie przykładów. W kontekście tych rozważań ważniejsze jest, że papież przywołał zasadę dogmatyczną z przemówienia Jana XXIII na otwarcie Soboru Watykańskiego II: „,W depozycie nauki chrześcijańskiej «czym innym jest istota [...], a czym innym jest sposób jej wyrażania»”, by przejść do zasady z ekumenicznej encykliki Jana Pawła II: „Pamiętajmy, że «wyrażanie prawdy może przybierać różne formy. Właśnie odnowa form wyrazu staje się konieczna, aby można było przekazywać współczesnemu człowiekowi ewangeliczne orędzie w jego niezmiennym sensie»»" (nr 41).

Obie przedstawione zasady tworzą jeden z fundamentów nauki o rozwoju dogmatów. Kolejny znajduje się w przemówieniu Benedykta

24 Benedykt XVI, Przemówienie do uczestników zgromadzenia plenarnego Papieskiej Rady Kultury, art. cyt.

25 MKT, Interpretacja dogmatów, dz. cyt., s. 277. 
XVI do PRK Nowe i kreatywne języki...: „W świecie, który komunikację traktuje jako zwycięską strategię, Kościół, któremu została powierzona misja głoszenia wszystkim ludziom Ewangelii zbawienia, nie pozostaje na nią obojętny i nie jest mu ona obca; przeciwnie, stara się korzystać [...] z nowych języków i nowych sposobów przekazu".

Te trzy zasady, tak silnie powiązane przez Benedykta XVI i Franciszka z kulturą współczesną, a zatem z kulturą popularną, z jej językami i komunikacją, sugerują potrzebę nowego spojrzenia na sprawę aktualizującej interpretacji doktryny i rozwoju dogmatów w perspektywie kultury popularnej. Jeśli w świetle tych zasad odczytamy naukę Katechizmu Kościoła katolickiego (1992), że „Broniąc zdolności rozumu ludzkiego do poznania Boga, Kościół wyraża swoją ufność w możliwość mówienia o Bogu wszystkim ludziom i z wszystkimi ludźmi" (nr 39), to musi tu chodzić także o wszystkich ludzi, którzy żyją w kulturze popularnej, którzy posługują się jej język (językami) i dla których jest ona horyzontem rozumienia i interpretacji świata i swego w nim miejsca. W konsekwencji, i jakkolwiek oceniać popkulturę, wydaje się, że z pomocą jej języka/ języków można głosić przesłanie chrześcijańskie o Bogu Miłości, również te jego aspekty ujęte w dogmatach wiary Kościoła, oczywiście z zastrzeżeniami, o których mowa zarówno w Katechizmie..., jak i w nauczaniu papieży:

- Katechizm... powtarza tradycyjną prawdę, że „Bóg przewyższa wszelkie stworzenia. Trzeba zatem nieustannie oczyszczać nasz język z tego, co ograniczone, obrazowe i niedoskonałe, by nie pomieszać «niewypowiedzianego, niepojętego, niewidzialnego i nieuchwytnego» Boga z naszymi ludzkimi sposobami wyrażania. Słowa ludzkie pozostają zawsze nieadekwatne wobec tajemnicy Boga" (nr. 42-43). Zastrzeżenie to dotyczy każdego języka o Bogu, czy to języka kultury wysokiej czy niskiej, kultury ludowej czy popkultury.

- Benedykt XVI, widząc konieczność korzystania z komunikacyjnych strategii świata, w tym samym przemówieniu do PRK podkreśla, że należy to robić ,z nowym, twórczym zaangażowaniem, ale także w sposób krytyczny i uważnie rozeznając". 
- Franciszek w Evangelii gaudium podkreśla dwie rzeczy: po pierwsze - „Każda kultura i każda grupa społeczna potrzebuje oczyszczenia i dojrzewania”, oraz po drugie - ,[...] nigdy nie będziemy w stanie sprawić, by nauczanie Kościoła było czymś łatwo zrozumiałym i docenianym przez wszystkich. Wiara zachowuje zawsze pewien aspekt krzyża, pewne ciemności, które nie podważają stanowczości w przylgnięciu do niej. Są takie rzeczy, które można zrozumieć i docenić, wychodząc jedynie od tego przylgnięcia, które jest siostrą miłości, niezależnie od jasności, z jaką można dostrzec racje i argumenty. Dlatego trzeba pamiętać, że każde nauczanie prawd wiary musi się odzwierciedlać w postawie ewangelizatora, który wzbudzi przylgnięcie serca przez bliskość, miłość i świadectwo" (nr 42).

\section{NOWE JĘZYKI}

Powtórzmy: proroctwa XX w. o sekularyzacji, która miała „zmieść” religię z powierzchni (przynajmniej) życia publicznego, nie spełniły się. Jak w 2004 r. ujął to kard. Paul Poupard: „Wszędzie obserwuje się spadek liczby osób regularnie uczęszczających do kościoła”, ale nie oznacza „upowszechnienia zjawiska niewiary; wskazuje raczej, że zmieniają się praktyka religijna i sposób wiary [...]"26. Oznacza to jednak, że przesłanie Kościoła domaga się inkulturacji nie tylko w gleby kultur regionów, gdzie chrześcijaństwo nigdy głębiej lub w ogóle nie zapuściło korzeni, ale także i na powrót regionów, które zwykło się określać tradycyjnie chrześcijańskimi. Dominuje tu dziś kultura popularna z językami, z pomocą których jak sugeruję - również można opowiedzieć Ewangelię, także te jej aspekty, które przybrały postać dogmatów.

26 P. Poupard, Ewangelizacja we współczesnym świecie, „L'Osservatore Romano" 2004, nr 5, s. 39-40, https:/opoka.org.pl/biblioteka/Z/ZS/osservatore/ osservatore052004.html (dostęp: 2.03.2018). 
Języki religijno-duchowe kultury popularnej, jakkolwiek je oceniać, zdaje się łączyć - inaczej niż w religijności wysokiej, wzniosłej, intelektualnej, abstrakcyjnej i chłodnej - niejaka przystępność, familiarność, prostota i ciepło. O sprawach duchowych mówi się tu zwykle z pomocą czytelnych obrazów, żywych porównań, znanych symboli, przemawiających do serca motywów, fabularności, cielesności, wydarzeniowości, konfliktowości, emocjonalności, z pomocą płynnych opowieści, amorficznych, niesamowitych, fantastycznych... Czyż nie przychodzą nam na myśl obrazowe, emocjonalne, sensualistyczne, niezwykłe, gorące, zadziwiające, nawet szokujące opowieści, obrazy, symbole, pytania i przypowieści Jezusa z Nazaretu i w ogóle Biblii?

Zjawisko nowej religijności - pisze Jarema Drozdowicz - ,polega [...] bardziej na wytworzeniu wspólnego języka, który przemawia do ludzi w sposób bardziej bezpośredni, daje poczucie familiarności, niesie popularną symbolikę, a jednocześnie proponuje wartości dające namiastkę transcendencji. Poprzez ten zabieg narracja religijnego dyskursu jest dziś zależna bezpośrednio od porządku popkultury, gdyż to ten porządek wyznacza kurs globalnego rozumienia, czym jest kultura jako taka. Powiązanie to jest odbierane przez wielu jako naturalna kolej rzeczy, a przynajmniej jako bardziej naturalne aniżeli anachroniczne teologiczne dysputy toczone za murami Watykanu"27. W podobnym duchu wyraża się Bogusław Dziadzia: „Praktyki popkulturowe w życiu religijnym odnajdujemy choćby w tym, iż bliższe są przeciętnemu chrześcijaninowi obrazy przedstawiające świętych, filmowe adaptacje historii biblijnych, aniżeli encykliki papieskie czy pisma świętego Tomasza z Akwinu"28.

Watykańskie dyskusje, owszem, mogą grzeszyć anachronizmem, trudno nie postawić jednak pytania - przynajmniej z teologicznego punktu widzenia - czy kultura popularna proponuje wyłącznie takie wartości, które kryją namiastkę transcendencji, czy też i takie, które autentycznie otwierają na transcendencję. Jeszcze raz Dziadzia: „Kultura popularna banalizuje wiele problemów [choć wiemy już dzisiaj, że nie

\footnotetext{
27 J. Drozdowicz, Popreligia $w$ dobie popkultury, dz. cyt., s. 232.

28 B. Dziadzia, Naznaczeni popkultura, dz. cyt., s. 169.
} 
musi to być jej cecha istotna - J. M.], których dotyka. Być może jednak opcja obcowania z sacrum, jaką ona proponuje, bliższa jest autentycznej relacji z transcendencją aniżeli jakikolwiek intelektualne podejście?"29

Można także pytać, czy rozwój dogmatów w historii teologii nie poszed $\nmid$ - przynajmniej z punktu widzenia dzisiejszej kultury zanadto w kierunku ujęcia intelektualistycznego, polegającego na logicznym, dedukcyjnym i racjonalnym rozwijaniu danych, które wiara bardziej lub mniej wyraźnie odnajduje w Objawieniu. Tego rodzaju czynnik czysto intelektualno-racjonalny odgrywa czy może odgrywać swoją rolę w rozwoju dogmatów, ale nie jest w stanie wyczerpać jego złożonej natury, o czym już w XIX w. - tj. w „starej” kulturze - przekonywał kard. John H. Newman ${ }^{30}$.

\section{ZAKONCZENIE}

W 1988 r. Andrew M. Greeley, katolicki duchowny, teolog i socjolog z USA, w studium God and Popular Culture postulował religijną i teologiczną rehabilitację popkultury, często krytykowanej przez elity jako wrogiej chrześcijaństwu. Nie wahał się twierdzić, że popkultura, ,jest locus theologicus, miejscem teologicznym, przestrzenią, gdzie można spotkać Boga"31. Jako taka, umożliwia ludziom „doświadczać Boga i opowiadać o Bogu czy, ujmując rzecz bardziej abstrakcyjnie, uczyć się o Bogu i uczyć innych o Nim"32.

Postulat teologiczno-dogmatycznego dowartościowania kultury popularnej wpisuje się w dziejową „słabość” Kościoła katolickiego do tego, co popularne w kulturze. Jak ujął to Greeley, spośród czterech religii i wyznań Księgi, czyli islamu, judaizmu, katolicyzmu

29 Tamże, s. 170.

30 J.H. Newman, O rozwoju doktryny chrześcijańskiej, (tłum.) J. W. Zielińska, Warszawa 1988.

31 A.M. Greeley, God in Popular Culture, Chicago 1988, s. 9. Por. C. M. Nanko-Fernández, Lo Cotidiano as Locus Theologicus, w: O. O. Espín (ed.), The Wiley Blackwell Companion to Latino/a Theology, Malden - Oxford 2015, s. 28-30; S.C. Napiórkowski, Jak uprawiać teologię, Wrocław 1998, s. 44-45.

32 Tamże. 
i protestantyzmu, to „katolicyzm ma najbardziej bogato rozwiniętą tradycję popularną, albowiem najmniej boi się wyobrażeniowego wymiaru religii. Innymi słowy, katolicyzm jest najbardziej sakramentalną z tych czterech [...]. To on najpewniej nie będzie się bał, że zbruka Boga, gdy posłuży się stworzeniem do tego, by Go opisać"33. Religia - podkreślał Amerykanin - jest aktywnością najpierw wyobrażeniową, a dopiero potem racjonalno-intelektualną.

W historii Kościoła tradycję wysoką rezerwowano dla dogmatów, dokumentów soborów i papieży czy do pism teologów, z kolei dla tradycji popularnej rezerwowano sztukę, muzykę, formy pobożności, kazania, exempla, żywoty świętych itd. Klasycznym przykładem Biblia pauperum, „Biblia biedaków”, przeznaczona dla illiterati, tych, którzy nie znali liter, więc dla ówczesnej absolutnej większości wiernych. Dzisiaj jednak, kiedy świat przeżywa nieustającą rewolucję technologiczno-komunikacyjną, z której wyłoniła się wszechogarniająca kultura popularna, doczesne i wieczne dobro jej mieszkańców, nas wszystkich - jak się zdaje - domaga się ,zstąpienia” dogmatów (w sensie szerszym i ścisłym) z wyżyn kultury wysokiej może już nie „pod strzechy”, bo te coraz częściej można spotkać tylko na skansenach, ale ,pod dachy” kultury popularnej. Język popkultury, podobnie jak język kultury wysokiej, ,zasługuje” dziś na to, by przemawiały nim dogmaty.

\section{Popkulturowy zwrot w rozwoju dogmatów?}

Streszczenie

Artykuł zajmuje się relacją między rozwojem dogmatów a kulturą popularną. Autor postuluje potrzebę ,popkulturowego zwrotu” w rozumieniu rozwoju dogmatów i aktualizującej interpretacji dogmatów. Sugeruje, że język (języki) kultury popularnej dojrzał do tego, by nazywać i przekazywać tajemnice wiary, którym Kościół nadał postać dogmatów sensie szerszym, tj. doktryna, nauczanie Kościoła,

${ }_{33}$ A.M. Greeley, The Catholic Imagination, Berkeley - Los Angeles - London 2000, s. 77. 
i dogmatów w sensie ścisłym (por. Międzynarodowa Komisja Teologiczna, Interpretacja dogmatów, III, 2-3)

\section{Pop-culture shift in the development of dogmas? Summary}

The article discusses the relationship between the development of dogmas and popular culture. The author proposes the need for a "pop-culture shift" in the understanding of the development of dogmas and the contemporary interpretation of dogmas. He suggests that the language (languages) of popular culture has matured enough to name and transmit the mysteries of faith to which the Church has given the form of dogmas in a wider sense, i.e. the teaching of the Church, and in the strict sense (cf. International Theological Commission, The Interpretation of Dogma, III, 2-3).

Słowa kluczowe: rozwój dogmatów, aktualizująca interpretacja dogmatów, popkultura, języki kultury popularnej, religijność popularna, ,popkulturowy zwrot”,

Keywords: development of dogmas, contemporary interpretation of dogmas, pop culture, languages of popular culture, popular religiosity, "pop-culture shift"

\section{BIBLIOGRAFIA (wybór):}

Bajerowa I., Szanse języka religijnego w świecie kultury masowej, w: Z. Adamek (red.), Teologia - kultura - wspótczesność, Tarnów 1995, s. 99-113.

Barański J., Antropologia, między przed-a ponowoczesnościq - garść wróżby na nowy wiek, „Konteksty” 2005, nr 4, s. 96-105.

Berger P., Sacks J. (ed.), The Desecularization of the World: Resurgent Religion and World Politics, Grand Rapids 1999.

Burszta W. J., Kultura popularna jako wspólnota uczuciowa, „Kultura Popularna” 2002, nr 0, s. 11-18.

Campbell H. A. (ed.), Digital Religion. Understanding Religious Practice in New Media Worlds, London - New York 2012.

Chachulski T. i in. (red.), Religijność w dobie popkultury, Warszawa 2014.

Christoffersen L. i in. (ed.), Religion in the 21st Century: Challenges and Transformations, Farnham-Burlington 2013.

Cybal-Michalska A., Wierzba P. (red.), Dyskursy kultury popularnej w spoteczeństwie współczesnym, Kraków 2012. 
Cybulska P., Majewski J., Narodziny popreligii. Religia w dobie kultury popularnej, „Sensus Historiae” 2017, vol. XXVII, s. 95-110.

Davie G., The Sociology of Religion: A Critical Agenda, London 2013.

Dobroczyński B., Trzecia Rzesza Popkultury, „Znak” 2004, nr 3, s. 16-31.

Drozdowicz J., Popreligia $w$ dobie popkultury, w: E. Jeliński i in. (red.), Ratio, religio, humanitas, Poznań 2015, s. 229-236.

Dziadzia B., Naznaczeni popkultura. Media elektroniczne i przemiany prowincji, Gdańsk 2014.

Espín O. O. (ed.), The Wiley Blackwell Companion to Latino/a Theology, Oxford 2015.

Godlewski G. i in. (red.), Animacja Kultury. Doświadczenie i przyszłość, Warszawa 2002.

Godlewski G., Słowo - pismo - sztuka słowa. Perspektywy antropologiczne, Warszawa 2008.

Greeley A. M., God in Popular Culture, Chicago 1988.

Greeley A. M., The Catholic Imagination, Berkeley - London 2000.

Guarino T. G., Vincent of Lérins and the Development of Christian Doctrine, Grand Rapids 2013.

Kawecki W., Kultura konsumpcyjna a wychowanie do kultury wysokiej, „Studia Theologica Varsaviensia" 2010, nr 2, s. 177-197.

Kijas Z., Rozwój dogmatów i jego kryteria, w: T. Dzidek i in. (red.) Teologia fundamentalna t. 5. Poznanie teologiczne, Kraków 1997, s. 72-87.

Lynch G. (ed.), Between Sacred and Profane: Researching Religion and Popular Culture, London 2007.

Lynch G., Understanding Theology and Popular Culture, Oxford 2005.

Majewski J., The Church in the Media Age, w: T. Buksiński (red.). Dilemmas of the Catholic Church in Poland, Washington 2015, s. 41-66.

Mariański J., Sekularyzacja, desekularyzacja, nowa duchowość. Studium socjologiczne, Kraków 2013.

Napiórkowski S. C., Jak uprawiać teologię, Wrocław 1998.

Newman J. H., O rozwoju doktryny chrześcijańskiej, (tłum.) J. W. Zielińska, Warszawa 1988.

Possamai A., Sociology of Religion for Generations X and Y, London - New York 2014.

Thiel J. E., The Development of Doctrine, w: J. Buckley, F. Ch. Bauerschmidt, T. Pomplun (ed.), The Blackwell Companion to Catholicism, Oxford 2011, s. 251-267. 
Turner B. S. (ed.), New Blackwell Companion to the Sociology of Religion, Oxford 2010.

Zowczak M., Religijność na pograniczach. Eseje apokryficzne, Warszawa 2014.

Dr hab. Józef Majewski, profesor Uniwersytetu Gdańskiego, teolog, antropolog mediów, kierownik Zakładu Dziennikarstwa i Mediów, członek Komitetu Naukowego Instytutu Analiz Społecznych i Dialogu „Laboratorium Więzi”. Członek kolegium redakcyjnego kwartalnika „Więź”, publicysta, dziennikarz, stały współpracownik „Tygodnika Powszechnego” i miesięcznika „Znak”. Autor, współautor i tłumacz 40 książek - autor m.in.: Miłość ukrzyżowana. Nad teologia cierpienia Jana Pawła II; Spór o rozumienie Kościoła. Eklezjologiczne uwarunkowania i perspektywy wielkich debat teologicznych na przełomie XX i XXI wieku; Teologia na rozdrożach; Religia - media - mitologia; Fuga przemijania. Stowo o eschatologii Jarosława Iwaszkiewicza; współautor m.in.: Puste piekło? Wokót ks. Wacława Hryniewicza nadziei zbawienia dla wszystkich; Leksykon wielkich teologów XX/XXI wieku (trzy tomy), Poronienie. Zrozumieć rodziców po stracie; Papież Franciszek. Stuga nowego świata; Celibat. Za i przeciw (e-book), Humanistyka w czasach pop (e-book), Dilemmas of the Catholic Church in Poland; Kościót. Komunikacja. Wizerunek; Media. Biznes. Kultura. Oblicza komunikacji medialnej; Liturgia. Muzyka. Język. O wspótczesnej komunikacji Kościoła. Redaktor prowadzący i współautor podręcznika akademickiego Dogmatyka (sześć tomów). Złożone do druku: Maryja $w$ dialogach ekumenicznych (t. XI serii Beatam me dicent; współautor, współredaktor, tłumacz); Kanony śmierci. Stowo o chrystologii ,Wariacji goldbergowskich” Jana Sebastiana Bacha. 